\title{
Univariate, multivariate techniques and mixed models applied to the adaptability and stability of wheat in the Rio Grande do Sul State
}

\author{
V.J. Szareski ${ }^{1}$, I.R. Carvalho ${ }^{2}$, K. Kehl ${ }^{3}$, A.M. Levien ${ }^{3}$, M. Nardino ${ }^{4}$, G.H. Demari ${ }^{1}$, \\ F. Lautenchleger ${ }^{5}$, V.Q. de Souza $^{6}$, T. Pedó ${ }^{1}$ and T.Z. Aumonde ${ }^{1}$ \\ ${ }^{1}$ Departamento de Fitotecnia, Universidade Federal de Pelotas, \\ Capão do Leão, RS, Brasil \\ ${ }^{2}$ Centro de Genômica e Fitomelhoramento, Universidade Federal de Pelotas, \\ Capão do Leão, RS, Brasil \\ ${ }^{3}$ Pesquisa e Desenvolvimento da Empresa Fundação Pró-Sementes, \\ Passo Fundo, RS, Brasil \\ ${ }^{4}$ Departamento de Matemática e Estatística, Universidade Federal de Pelotas, \\ Capão do Leão, RS, Brasil \\ ${ }^{5}$ Departamento de Agronomia, Universidade Estadual de Maringá, \\ Maringá, PR, Brasil \\ ${ }^{6}$ Universidade Federal do Pampa, Dom Pedrito, RS, Brasil \\ Corresponding author: V.J. Szareski \\ E-mail: viniciusszareski@gmail.com
}

Genet. Mol. Res. 16 (3): gmr16039735

Received May 25, 2017

Accepted July 10, 2017

Published July 28, 2017

DOI http://dx.doi.org/10.4238/gmr16039735

Copyright $(2017$ The Authors. This is an open-access article distributed under the terms of the Creative Commons Attribution ShareAlike (CC BY-SA) 4.0 License.

\begin{abstract}
The wheat crop presents sensitivity to the environmental conditions culminating in the genotype $\mathrm{x}$ environment interaction, being crucial the use of different methodologies to guide the positioning of genotypes to certain cultivation environments. The objective of this study was to estimate the adaptability and phenotypic stability of wheat genotypes grown in the State of Rio Grande do Sul using univariate and multivariate techniques and mixed models. The yield data of 42
\end{abstract}

Genetics and Molecular Research 16 (3): gmr16039735 
wheat genotypes evaluated in five environments (Cachoeira do Sul, Passo Fundo, Santo Augusto, São Gabriel, and São Luiz Gonzaga) were used in the 2012 and 2013 crop seasons. In each experiment, a randomized complete block design was used, with three replicates. In the evaluation of the genotype $\mathrm{x}$ environment interaction, the sum of squares relative to contribution index, the methodology based on the univariate method of Annicchiarico (1992), the multivariate method (AMMI), and the mixed models (REML and MHPRVG) were used. The favorable environments expressed by the univariate method referred to São Gabriel, Cachoeira do Sul, Passo Fundo, Santo Augusto, and São Luiz Gonzaga; for the multivariate method, only Santo Augusto was favorable to the productivity character. The genotypes CD 121 and TBIO Tibagi were adapted and stable for the univariate and multivariate methods. The genotypes TBIO Sinuelo, Quartzo, BRS 327, Mirante, Topázio, Guamirim, TBIO Seleto, Ametista, TBIO Mestre, and BRS Louro were superior through the mixed model approach. The different strategies to estimate the adaptability and phenotypic stability allowed indicating and recommending the best environments and genotypes efficiently to obtain increases in wheat grain yield.

Key words: Triticum aestivum L.; Genotype x environment interaction; Annicchiarico (1992); AMMI and grain yield

\section{INTRODUCTION}

The grain yield of wheat (Triticum aestivum L.) is determined by the expression of the genetic characteristics, effect of the growing environment and interaction between these factors (Allard, 1971). In this way, the differential response of genotypes cultivated in different environments is conceptualized as the interaction of genotypes $\mathrm{x}$ environments $(\mathrm{G} \times \mathrm{E})$, which directly influences the phenotypic and genetic relationship, affects the recommendation of the genotypes for certain cultivation conditions (Cruz et al., 2014). Due to the effects of this interaction, alternatives are sought to infer recommendations of genotypes for specific environments (Campbell and Jones, 2005).

In this context, several statistical methods were developed to identify and quantify the effects of genotypes and environments, making it possible to interpret biological phenomena using these tools. It is seeking an ideal genotype that reveals high production levels, a wide phenotypic stability, presents less sensitivity to the adverse conditions imposed by hostile environments, and that is responsive to favorable environments (Cruz et al., 2014; Da Silva et al., 2016).

Methodologies based on analysis of variance, as the method of Annicchiarico (1992), allow to infer about the phenotypic stability, reveal indexes based on the performance of the genotype average, effects of the environment and obtain a trust index to define if the genotype is superior or inferior in relation to the others, and jointly establishes an environmental index that indicates which are the favorable and unfavorable environments (Cruz et al., 2014). In wheat culture, this method was used by (Amorim et al., 2006; Condé et al., 2010).

It is essential to reveal the contribution of the various factors to the total variation of the character, this alternative makes it possible to use the relative contribution of the sum of

Genetics and Molecular Research 16 (3): gmr16039735 
squares of the genotypes and culture environments for the interaction, defining the treatment levels that more influenced the $\mathrm{G} \times \mathrm{E}$ interaction for the grain yield character of the wheat. Similarly, the use of multivariate techniques and Biplot graphical analyses facilitates the inferences for the complex interactions, allows less biased interpretations, and the information generated is expressed simply and reliably (Ma et al., 2004).

In this context, the use of the AMMI technique (additive main effects and multiplicative interaction analysis) combines analysis of variance (univariate) and the main components (multivariate), where it adjusts the effects of genotypes, environments, and $\mathrm{G} \times \mathrm{E}$ interaction (Zobel et al., 1988; Silva and Benin, 2012). This statistical technique is composed of an additive fraction that brings together the general average, the genotypic and environmental effects, the residual effects composed by the multiplicative proportion of the model, and then the additive and multiplicative terms of the G x E interaction (Silva and Benin, 2012). The AMMI analysis has been used in crops of agronomic interest such as wheat (Ma et al., 2004; Silva et al., 2011; Rodríguez et al., 2011; Castillo et al., 2012; Ahmadi et al., 2012; Benin et al., 2012).

By using the statistical approach based on restricted maximum likelihood (REML), it is possible to obtain the highest agronomic efficiency in the estimation of variance components and genetic parameters, where a ranking with the index of adapted and stable genotypes is applied, based on the genetic effects (Resende, 2002). These inferences use an approach of the linear mixed models that have been widely used in annual crops, and in the same way, autogamy is a good strategy to improve the efficiency in the positioning of genotypes (Ramalho and Araújo, 2011). This procedure allows obtaining more precise estimates of genetic parameters (Resende, 2016).

The use of different methodologies to guide the positioning of genotypes in certain environments is crucial because it allows understanding which wheat genotypes are specific to certain growing environments. In this context, the objective of this study was to estimate the adaptability and phenotypic stability of wheat genotypes grown in the State of Rio Grande do Sul through univariate, multivariate, and mixed models.

\section{MATERIAL AND METHODS}

\section{Growing environments}

The experiments were conducted in the crops of 2012 and 2013 in five environments of Rio Grande do Sul, Brazil. Detailed information on the environments is shown in Table 1.

Table 1. Geographic information, soil type, altitude (Alt.) referring to the five cultivation environments and crops.

\begin{tabular}{l|l|l|l|c|l}
\hline Acronym & Crop & Cultivation environment & Geographical coordinate & Alt. (m) & Soil type \\
\hline A1 & 2012 & Cachoeira do Sul-RS & $30^{\circ} 177^{\prime} 52^{\prime \prime} S-52^{\circ} 57^{\prime} 54^{\prime \prime} \mathrm{W}$ & 113 & Sandy Haplic Planosol \\
\hline A2 & 2012 & Passo Fundo-RS & $28^{\circ} 13^{\prime} 17^{\prime \prime} \mathrm{S}-52^{\circ} 19^{\prime} 39^{\prime \prime} \mathrm{W}$ & 709 & Typical Red Latosol \\
\hline A3 & 2012 & Santo Augusto-RS & $27^{\circ} 54^{\prime} 47^{\prime \prime} \mathrm{S}-53^{\circ} 49^{\prime} 04^{\prime \prime} \mathrm{W}$ & 503 & Typical Red Latosol \\
\hline A4 & 2012 & São Gabriel-RS & $30^{\circ} 20^{\prime} 09^{\prime \prime} \mathrm{S}-54^{\circ} 10^{\prime} 21^{\prime \prime} \mathrm{W}$ & 159 & Sandy Haplic Planosol \\
\hline A5 & 2012 & São Luiz Gonzaga-RS & $28^{\circ} 24^{\prime} 42^{\prime \prime} \mathrm{S}-54^{\circ} 45^{\prime} 45^{\prime \prime} \mathrm{W}$ & 270 & Typical Red Latosol \\
\hline A6 & 2013 & Cachoeira do Sul-RS & $30^{\circ} 17^{\prime} 52^{\prime \prime} \mathrm{S}-52^{\circ} 57^{\prime} 54^{\prime \prime} \mathrm{W}$ & 113 & Sandy Haplic Planosol \\
\hline A7 & 2013 & Passo Fundo-RS & $28^{\circ} 13^{\prime} 17^{\prime \prime} \mathrm{S}-52^{\circ} 19^{\prime} 39^{\prime \prime} \mathrm{W}$ & 709 & Typical Red Latosol \\
\hline A8 & 2013 & Santo Augusto-RS & $27^{\circ} 54^{\prime} 47^{\prime \prime} \mathrm{S}-53^{\circ} 49^{\prime} 04 " \mathrm{~W}$ & 503 & Typical Red Latosol \\
\hline A9 & 2013 & São Gabriel-RS & $30^{\circ} 20^{\prime} 09^{\prime \prime} \mathrm{S}-54^{\circ} 10^{\prime} 21^{\prime \prime} \mathrm{W}$ & 159 & Sandy Haplic Planosol \\
\hline A10 & 2013 & São Luiz Gonzaga-RS & $28^{\circ} 24^{\prime} 42^{\prime \prime S}-54^{\circ} 45^{\prime} 45^{\prime \prime} \mathrm{W}$ & 270 & Typical Red Latosol \\
\hline
\end{tabular}

Streck et al. (2008).

Genetics and Molecular Research 16 (3): gmr16039735 


\section{Experimental conditions and genotypes used}

The experimental design was the randomized block, organized in a factorial scheme with ten cultivation environments (referring to the combination of crops and cultivation environments) x 42 wheat genotypes recommended for the State of Rio Grande do Sul, with three replicates. The genotypes used were: Abalone, Ametista, BRS 296, BRS 327, BRS 328, BRS 331, BRS 374, BRS Guabiju, BRS Guamirim, BRS Louro, BRS Umbu, Campeiro, CD 114, CD 117, CD 119, CD 120, CD 121, CD 122, CD 123, FPS Nitron, Fundacep 52, Fundacep Bravo, Fundacep Campo Real, Fundacep Cristalino, Fundacep Horizonte, Fundacep Nova Era, Fundacep Raízes, JF 90, Marfim, Mirante, Onix, Quartzo, Safira, Supera, TBIO Alvorada, TBIO Iguaçu, TBIO Itaipu, TBIO Mestre, TBIO Seleto, TBIO Sinuelo, TBIO Tibagi, and Topázio.

The experimental units consisted of five sowing rows spaced by $0.20 \mathrm{~m}$ and $5 \mathrm{~m}$ in length. The sowing of the crop environments for both crops occurred between the second fortnight of May and the first fortnight of June of each crop. The population density used was 330 viable seeds per square meter. The nutritional management consisted of $250 \mathrm{~kg} / \mathrm{ha}$ NPK in the formulation $08-25-20$ at the sowing, $50 \mathrm{~kg} / \mathrm{ha}$ nitrogen, for top dressing, with urea $(46 \% \mathrm{~N})$ in a single application at tillering stage. Weed, pest insects, and disease management were standardized for all environments and genotypes, following the wheat technical recommendations.

Grain productivity was obtained by harvesting the useful area of each experimental unit $\left(5.0 \mathrm{~m}^{2}\right)$, the grain mass was adjusted to $13 \%$ of moisture and subsequently adapted to $\mathrm{kg} / \mathrm{ha}$.

\section{Statistical analysis}

The data were submitted to analysis of individual variance for each growing environment, to identify if the model met the assumptions (Ramalho et al., 2000). Subsequently, a joint analysis was carried out to identify the presence of the interaction between growing environments and wheat genotypes at $5 \%$ of probability. When identifying the interaction, it was separated the interaction sum of squares from the simple effects, and a relative contribution index of the sum of squares (RC_SS_INT) was obtained, revealing which were the treatment levels that most influenced the $\mathrm{G} \times \mathrm{E}$ interaction.

Later, the Annicchiarico (1992) phenotypic stability and adaptability methods were applied based on the model $\omega \mathrm{i}=\mu-\mathrm{z}(1-\alpha) \sigma z \mathrm{z}$, where $\omega \mathrm{i}$ is a confidence index expressed as a percentage; $\mu$ is the average of the genotype $i$; $z$ is the percentile of the cumulative normal distribution function; $\alpha$ is the level of significance assigned; $\sigma \mathrm{zi}$ is the standard deviation of the percentage values (Cruz et al., 2014). It was applied a multivariate AMMI method that combines the variances of the additive effects of genotypes and environments, together with the multiplicative effect of the G x E interaction, where the inferences obtained are Biplot exposed through analysis of major components (Zobel et al., 1988).

The model: $Y_{i j}=\mu+g_{i}+a_{j}+\sum_{k=1}^{n} \lambda_{k} y_{i k} \alpha_{j k}+\rho_{i j}+\varepsilon i j$ was followed, where $\mathrm{Y}_{\mathrm{ij}}$ is the average response of the repeats of the ith genotype $(i=1,2,3, \ldots, g)$ in the jth environment $(j=1$, $2,3, \ldots, \mathrm{e}) ; \mu$ is the average of all genotypes in all environments (general average); gi is the main effect of genotype $i$; aj is the main effect of environment $j ; \Lambda \mathrm{k}, \mathrm{y}_{\mathrm{ik}}$ and $\alpha_{\mathrm{jk}}$ are the terms of the singular decomposition of the GE matrix $\mathrm{g} \mathrm{x} \mathrm{e}=\left\{(\mathrm{ge})_{\mathrm{ij}}\right\}$, which express and capture the "pattern" associated with the interaction of genotype $i$ with environment $j$, where $(g e)_{i j}$ are the additivity deviations of data $\left(\mathrm{Y}_{\mathrm{ij}}\right)$ in relation to the main effects gieaj; $\rho_{\mathrm{ij}}$ is an additional noise

Genetics and Molecular Research 16 (3): gmr16039735 
to be eliminated in the analysis, relative to the term $(\mathrm{ga})_{\mathrm{ij}}$, taken as the interaction, and $\varepsilon_{\mathrm{ij}}$ is the experimental error (Duarte and Vencovsky, 1999).

The method based on the REML was applied, where a deviance analysis was obtained for the purpose of identifying significance for the parameters of $5 \%$ probability for the quadruple test, then the components of variance and genetic parameters were estimated (Spilke et al., 2005). The statistical model 54 was used to obtain joint adaptation and stability inferences by classification (MHPRVG) obtained by harmonic means weighted by genotypic values (Resende, 2007). As statistical analyses were performed on the Genes software (Cruz, 2013), program R (R Core Team, 2015), and Selegen (Resende, 2007).

\section{RESULTS AND DISCUSSION}

Analysis of variance at $5 \%$ of probability revealed interaction for crop environments $\mathrm{x}$ wheat genotypes for grain yield, and this allowed obtaining estimates of adaptability and phenotypic stability. The experiment showed a coefficient of variation of $20 \%$ according to the classification of Pimentel Gomes (2009), the experiment was conducted appropriately, and the estimates are well-founded and reliable. The general average of the experiment for grain yield was $4054 \mathrm{~kg} / \mathrm{ha}$. Data from the National Supply Company showed that the average national grain yield for the wheat crop in the 2012 and 2013 crops was $2311 \mathrm{~kg} / \mathrm{ha}$, and for the Rio Grande do Sul State it was $1941 \mathrm{~kg} / \mathrm{h}$. Therefore, the results obtained were $42.9 \%$ above the national average, and 52.1\% above the Rio Grande do Sul average (CONAB - Companhia Nacional de Abastecimento, 2012).

Based on the inferences obtained by the relative contribution of sum of squares to the interaction (RC_SS_INT), it was observed that environments A6 (Cachoeira do Sul - RS, agricultural crop 2013), A4 (São Gabriel - RS, agricultural crop 2012), A1 (Cachoeira do Sul RS, agricultural crop 2012), and A8 (Santo Augusto - RS, agricultural crop 2013), contributed in a superior way to the interaction (Table 2), that is, they are environments that may present lower phenotypic stability for the testing and positioning of wheat genotypes. On the other hand, the environments A2 (Passo Fundo - RS, agricultural crop 2012), A3 (São Augusto - RS, agricultural crop 2012), A5 (São Luiz Gonzaga - RS, agricultural crop 2012), and A9 (São Gabriel - RS, agricultural crop 2013) were those environments that less contributed to the G $\mathrm{x} E$ interaction, not revealing abrupt changes in the productive performance of the genotypes.

Concerning the genotypes, greater stability was observed based on RC_SS_INT for the genotypes Ametista, BRS 328, CD 114, CD 117, CD 122, CD 123, Fundacep Bravo, Fundacep Cristalino, Fundacep Nova Era, Onix, TBIO Alvorada, and TBIO Seleto related to the tested environments. However, the genotypes Mirante, Fundacep 52, BRS 374, CD 121, Fundacep Campo Real, BRS Guabiju, TBIO Sinuelo, BRS 296, BRS 331, Quartzo, TBIO Mestre, BRS Umbu, Supera, CD 119, Campeiro, JF 90, TBIO Tibagi, Topázio, and BRS Louro were the genotypes that most influenced the $\mathrm{G} x \mathrm{E}$ interaction, which implies greater care in the positioning in the growing environments.

The Annicchiarico method (1992) allowed to classify as favorable the environments A4 (São Gabriel - RS, agricultural crop 2012), A6 (Cachoeira do Sul - RS, agricultural crop 2013), A7 (Passo Fundo - RS, agricultural crop 2013), A8 (Santo Augusto - RS, agricultural crop 2013), A9 (São Gabriel - RS, agricultural crop 2013), and A10 (São Luiz Gonzaga - RS, agricultural crop 2013). On the other hand, the environments A1 (Cachoeira do Sul - RS, agricultural crop 2012), A2 (Passo Fundo - RS, agricultural crop 2012), A3 (São Augusto -

Genetics and Molecular Research 16 (3): gmr16039735 
RS, agricultural crop 2012), and A5 (São Luiz Gonzaga - RS, agricultural crop 2012) were unfavorable (Table 2). Wheat is a plant favored by cold conditions and its performance is superior in regions with low temperatures, because excess heat and low altitudes are responsible for the decrease of grain yield, where they result in the development and early senescence, respiration increase and the reduction of photosynthesis; these obstacles can be minimized with the use of adapted genotypes and directed to the most promising cultivation environments (Oliveira et al., 2011).

The Annicchiarico method (1992) showed stability for the genotypes TBIO Sinuelo (16.8\%), Quartzo (15.6\%), BRS 327 (13.7\%), Mirante (12.6\%), TBIO Seleto (10.2\%), BRS Guamirin (9.7\%), Topázio (9.5\%), Ametista (7.6\%), and BRS Louro (6.2\%). These genotypes remained stable for grain yield in the study environment. However, genotypes CD 117 $(-13.7 \%)$, BRS $331(-12.6 \%)$, CD $123(-12.1 \%)$, and CD $120(-11.5 \%)$ were not stable in general (Table 2). The positioning of wheat genotypes with high performance is essential to increase the profitability of the farmer, but some situations such as the minimum limits of altitude, sowing season, climatic conditions, soil characteristics, abiotic factors, and $\mathrm{G} \times \mathrm{E}$ interaction complicate decision making regarding the positioning of genotypes.

For the environments classified as favorable (A4, A6, A7, A8, A9, and A10), the genotypes Mirante (16.8\%), TBIO Sinuelo (16.3\%), Quartzo (15.7\%), BRS $327(9.6 \%)$, Topázio (7.9\%), BRS Louro (7.4\%), and TBIO Mestre (6.2\%). Research by Condé et al. (2010) evaluated wheat genotypes and verified that the Annicchiarico method (1992) was efficient to determine which genotypes and environments were favorable for grain yield. However, the genotypes CD 117 (-15.8\%), CD 123 (-15.5\%), Fundacep Nova Era (-9.8\%), BRS Guabiju $(-9.3 \%)$, Safira $(-8.3 \%)$, BRS $328(-8.3 \%)$, and CD $120(-8.2 \%)$ were not satisfactory for favorable environments (Table 2).

Table 2. Stability estimates by the Annicchiarico method (1992), and the relative contribution by the sum of squares of the interaction (RC_SS_INT) for grain yield ( $\mathrm{kg} / \mathrm{ha}$ ) measured in 42 wheat genotypes grown in Cachoeira do Sul RS, Passo Fundo - RS, Santo Augusto - RS, São Gabriel - RS, and São Luiz Gonzaga - RS in the crops 2012 and 2013.

\begin{tabular}{|c|c|c|c|c|c|c|c|c|c|}
\hline Genotypes & RC SS INT & General (\%) & Favorable (\%) & Unfavorable (\%) & Genotypes & RC SS INT & General (\%) & Favorable (\%) & Unfavorable (\%) \\
\hline Abalone & $2.2 * \%$ & 98.6 & 93.4 & 106.3 & Fundacep Bravo & $1.9 * \%$ & 96.1 & 95.0 & 97.8 \\
\hline Ametista & $1.9 * \%$ & 107.6 & 103.9 & 113.3 & Fundacep Campo Real & $3.3 * \%$ & 94.6 & 103.5 & 81.3 \\
\hline BRS 296 & $2.9 * \%$ & 93.6 & 100.3 & 83.6 & Fundacep Cristalino & $1.4 \% \%$ & 97.7 & 94.1 & 103.0 \\
\hline BRS 327 & $2.2 * \%$ & 113.7 & 109.6 & 120.0 & Fundacep Horizonte & $2.1 \% \%$ & 100.2 & 99.3 & 101.4 \\
\hline$\overline{\text { BRS } 328}$ & $1.6 \% \%$ & 91.5 & 91.7 & 91.2 & Fundacep Nova Era & $1.6 \% \%$ & 91.8 & 90.2 & 94.3 \\
\hline BRS 331 & $2.8 * \%$ & 87.4 & 94.5 & 76.7 & Fundacep Raizes & $2.0 \% \%$ & 97.0 & 99.5 & 93.2 \\
\hline BRS 374 & $3.3 * \%$ & 100.6 & 102.2 & 98.0 & JF 90 & $2.5 * \%$ & 91.9 & 97.7 & 83.2 \\
\hline BRS Guabiju & $3.0 * \%$ & 93.6 & 90.7 & 97.9 & Marfin & $2.3 * \%$ & 101.0 & 101.9 & 99.6 \\
\hline BRS Guamirin & $2.2 * \%$ & 109.7 & 104.1 & 118.0 & Mirante & $3.6 \% \%$ & 112.6 & 116.8 & 106.2 \\
\hline$\frac{\text { BRS Uuarnitin }}{\text { BRS Louro }}$ & $\frac{2.2 \%}{2.4 * \%}$ & $\frac{109.1}{106.2}$ & $\frac{104.1}{107.4}$ & 1184.4 & $\begin{array}{l}\text { Ondrante }^{2} \\
\text { Onix }\end{array}$ & 年.0\% & $\begin{array}{ll}112.0 \\
96.9\end{array}$ & $\frac{11.8}{97.0}$ & $\frac{10.2}{96.8}$ \\
\hline BRS Umbu & $2.6 \% \%$ & 102.0 & 103.9 & 99.0 & Quartzo & $2.7 * \%$ & 115.6 & 115.7 & 115.5 \\
\hline Campeiro & $2.5 \% \%$ & 103.2 & 105.7 & 99.5 & Safira & $2.3 * \%$ & 93.7 & 91.7 & 96.7 \\
\hline CD 114 & $1.9 * \%$ & 100.2 & 95.1 & 107.9 & Supera & $2.5 \% \%$ & 97.2 & 101.1 & 91.3 \\
\hline CD 117 & $1.8 \% \%$ & 86.7 & 84.2 & 90.3 & TBIO Alvorada & $1.7 * \%$ & 102.7 & 98.8 & 108.6 \\
\hline CD 119 & $2.5 * \%$ & 90.8 & 93.8 & 86.1 & TBIO Iguaçu & $2.2 * \%$ & 100.1 & 97.5 & 103.8 \\
\hline CD 120 & $2.3 * \%$ & 88.5 & 91.8 & 83.6 & TBIO Itaipu & $2.1 * \%$ & 104.4 & 101.7 & 108.4 \\
\hline CD 121 & $3.3 * \%$ & 100.1 & 101.4 & 98.2 & TBIO Mestre & $2.7 * \%$ & 106.2 & 106.2 & 106.2 \\
\hline $\mathrm{CD} 122$ & $1.6 \% \%$ & 97.5 & 96.7 & 98.7 & TBIO Seleto & $1.5 \% \%$ & 110.2 & 102.4 & 121.9 \\
\hline CD 123 & $1.4 \% \%$ & 87.9 & 84.5 & 93.1 & TBIO Sinuelo & $2.9 \% \%$ & 116.8 & 116.3 & 117.5 \\
\hline FPS Nitron & $\frac{1.4 \%}{2.3 * \%}$ & 101.9 & $\frac{0.53}{103.3}$ & $\frac{95.1}{99.8}$ & $\begin{array}{l}\text { TBIO Tibagi } \\
\text { TBIO }\end{array}$ & $\frac{2.9 \%}{2.4 * \%}$ & $\frac{110.0}{105.6}$ & $\frac{110.3}{106.8}$ & $\frac{11.3}{103.7}$ \\
\hline Fundacep 52 & $3.4 \% \%$ & 95.1 & 98.5 & 89.9 & Topázio & $2.2 * \%$ & 109.5 & 107.9 & 111.7 \\
\hline \multicolumn{5}{|c|}{ Growing environment } & Index & \multicolumn{2}{|c|}{ RC SS INT (\%) } & \multicolumn{2}{|l|}{ Class } \\
\hline \multirow{2}{*}{\multicolumn{2}{|c|}{$\begin{array}{l}\mathrm{A} 1 \\
\mathrm{~A} 2\end{array}$}} & \multirow{2}{*}{\multicolumn{3}{|c|}{\begin{tabular}{|l|} 
Cachoeira do Sul - RS, agricultural crop 2012 \\
Passo Fundo - RS, agricultural crop 2012
\end{tabular}}} & -879.9 & \multirow{2}{*}{\multicolumn{2}{|c|}{$\frac{14.1^{*}}{1.2}$}} & \multirow{2}{*}{\multicolumn{2}{|c|}{\begin{tabular}{|l} 
Untavorable \\
Unfavorable \\
\end{tabular}}} \\
\hline & & & & & -2.359 .3 & & & & \\
\hline \multicolumn{2}{|l|}{$\frac{\mathrm{AL}}{\mathrm{A} 3}$} & \multicolumn{3}{|c|}{ Santo Augusto - RS, agricultural crop 2012} & $\frac{-2.359 .5}{-1.750 .2}$ & \multicolumn{2}{|c|}{4.9} & \multicolumn{2}{|l|}{\begin{tabular}{|l} 
Unfavorable \\
\end{tabular}} \\
\hline \multirow{2}{*}{\multicolumn{2}{|c|}{$\frac{\mathrm{AS}}{\mathrm{A} 4}$}} & \multicolumn{3}{|c|}{ São Gabriel - RS, agricultural crop 2012} & 63.0 & \multirow{2}{*}{\multicolumn{2}{|c|}{$14.7^{*}$}} & \multicolumn{2}{|l|}{\begin{tabular}{|l|l|} 
Favorable \\
\end{tabular}} \\
\hline & & \multirow{2}{*}{\multicolumn{3}{|c|}{$\begin{array}{l}\text { São Luiz Gonzaga - RS, agricultural crop } 2012 \\
\text { Cachoeira do Sul - RS, agricultural crop } 2013\end{array}$}} & -802.2 & \multirow{2}{*}{\multicolumn{2}{|c|}{$\begin{array}{ll}3.8 \\
19.3 *\end{array}$}} & \multirow{2}{*}{\multicolumn{2}{|c|}{\begin{tabular}{|l|} 
Unfavorable \\
Favorable
\end{tabular}}} \\
\hline \multicolumn{2}{|l|}{$\frac{\mathrm{AS}}{\mathrm{A} 6}$} & & & & 1.462 .6 & & & & \\
\hline \multirow{2}{*}{\multicolumn{2}{|c|}{$\frac{\mathrm{A} 7}{\mathrm{~A} 8}$}} & \multirow{2}{*}{\multicolumn{3}{|c|}{$\begin{array}{l}\text { Passo Fundo - RS, agricultural crop } 2013 \\
\text { Santo Augusto - RS agricultural crop } 2013\end{array}$}} & 824.6 & \multicolumn{2}{|c|}{$9.6^{*}$} & \multicolumn{2}{|l|}{ Favorable } \\
\hline & & & & & 2.173 .4 & \multicolumn{2}{|c|}{$13.9^{*}$} & \multicolumn{2}{|l|}{$\begin{array}{ll}\text { Favordic } \\
\text { Favorable }\end{array}$} \\
\hline \multicolumn{2}{|l|}{$\frac{A O}{A 9}$} & \multicolumn{3}{|c|}{$\begin{array}{l}\text { Santo Augusto - RS, agricultural crop } 2013 \\
\text { São Gabriel - RS, agricultural crop } 2013\end{array}$} & 917.8 & & & Favorable & \\
\hline \multicolumn{2}{|l|}{$\frac{\mathrm{A} 9}{\mathrm{~A} 10}$} & São Luiz Gonza & - RS, agricultura & crop 2013 & 350.1 & & & Favorable & \\
\hline
\end{tabular}

*Significance at $5 \%$ of probability by the F-test for each level of the variation factor. 
In the environments classified as unfavorable (A1, A2, A3 and A5), the genotypes TBIO Seleto (21.9\%), BRS 327 (20\%), BRS Guamirin (18\%), TBIO Sinuelo (17.5\%), Quartzo (15.5\%), Ametista (13.3\%), and Topázio (11.7\%) highlighted. These genotypes may be recommended for environments with conditions not ideal for wheat. On the other hand, genotypes BRS 331 (-23.3\%), Fundacep Campo Real (-18.7\%), JF 90 (-16.8\%), BRS 296 (-16.4\%), CD 120 (-16.4\%), CD 119 (-13.9\%), and Fundacep 52 (-10.1\%) were the most demanding genotypes regarding the intrinsic conditions of the crop environment (Table 2). In this study, $52 \%$ of the genotypes were higher than the general trust index obtained for grain yield in the Annicchiarico method (1992). Junior (2014) surveys evaluated wheat genotypes in ten growing environments in two crops and revealed that only $28 \%$ of the genotypes were considered stable for grain yield using the Annicchiarico method (1992). According to Pereira et al. (2009), this method is efficient to indicate the most stable genotypes.

AMMI analysis shows the effects of genotype, environment, and G x E interaction together. This simultaneous representation provides information regarding stability and phenotypic adaptability, which allows the agronomic zoning and the selection of the best genotypes (Yokomizo et al., 2013). The more the first IPCA axis of the AMMI analysis explains the total character variation, the greater the "standard" percentage with the less noise or errors attributed to the analysis (Oliveira et al., 2003). It was observed for the first axis (EPCA1) significant effect representing $86.2 \%$ of the sum of squares of the $\mathrm{G} x \mathrm{E}$ interaction. This proportion is relatively above the variation commonly observed in other soybean crop research, 43.1\% (Silveira et al., 2016), 44\% (Yokomizo et al., 2013), and 36\% (Oliveira et al., 2003), which indicates that the effects of genotypes, environments, and $\mathrm{G} x \mathrm{E}$ interaction were well represented by the estimates obtained.

This model is relatively simple and presents few multiplicative terms, where it provides differential estimates for the genotypes (Yokomizo et al., 2013). Research by Silva and Benin (2012) demonstrated the effectiveness of the AMMI model to select the best cultivation environments and the most suitable genotypes for each situation. Benin et al. (2012) showed the response of eight wheat genotypes grown in two crops under four management levels, where $73 \%$ of the effects were due to the environment for grain yield. Ahmadi et al. (2012) evaluated 35 wheat strains grown in seven environments for two crops, where AMMI made it possible to represent the genetic and environmental effects in a collective way for grain yield.

In Figure 1 it can be observed that the genotypes or environments located near the origin of the coordinate system of the Biplot graph were considered more stable; however, the greater the distance from the source the lower the stability related to the grain yield character; these effects are due to the nature of the G x E interaction (Duarte and Vencovsky, 1999). A genotype is considered adapted to a particular environment when it is situated in the same quadrant of the environment (Yan and Kang, 2003).

It can be inferred that only the A3 environment (Santo Augusto - RS, agricultural crop 2012) was stable where it revealed the lowest contribution to the $\mathrm{G} \times \mathrm{E}$ interaction captured by the axis (IPCA1: -0.759). However, for this environment, grain yield was lower than the general average of the experiment $2272.1 \mathrm{~kg} / \mathrm{ha}$, which is indispensable for the positioning of genotypes capable of responding to the improvement of environmental conditions (Figure 1 and Table 3). Among the highly productive and unstable environments there were A4 (São Gabriel - RS, agricultural crop 2012), A6 (Cachoeira do Sul - RS, agricultural crop 2013), A7 (Passo Fundo - RS, agricultural crop 2013), A8 (Santo Augusto - RS, agricultural crop 2013), A9 (São Gabriel - RS, agricultural crop 2013), and A10 (São Luiz Gonzaga - RS, agricultural

Genetics and Molecular Research 16 (3): gmr16039735 
crop 2013). Four situations distinguish the genotypes, the first grouping the genotypes with high grain yields with magnitudes above the general average of the experiment, stable that contribute little to the $\mathrm{G} \times \mathrm{E}$ interaction, the second grouping the genotypes with grain yield below the general average of the experiment, but stable, the third represents the genotypes with high and unstable grain yield with higher contribution to the $\mathrm{G} \times \mathrm{E}$ interaction, and the fourth fraction is represented by genotypes with low and unstable grain yield (Alvarez and Eyhérabide, 1996).

The stable genotypes with high productive potential expressed by the AMMI analysis were CD 121 (G17: 0.498) and TBIO Tibagi (G41: 0.963); these genotypes obtained higher grain yields than the general average of the experiment ( 0.8 and $5.3 \%$, respectively) (Table 3 and Figure 1). It was verified that the genotypes Ametista, BRS 327, BRS 324, BRS Guamirim, BRS Louro, BRS Umbu, Campeiro, FPS Nitron, Fundacep Horizonte, Marfim, Mirante, Quartzo, TBIO Alvorada, TBIO Iguaçu, TBIO Itaipu, TBIO Mestre, TBIO Seleto, TBIO Sinuelo, and Topázio showed high productive potential but were unstable, with specific adaptability to certain environments, which requires greater caution to infer about the correct positioning of the genotypes (Figure 1 and Table 3).

Research has shown that unstable genotypes with high grain yields should not be discarded due to their specific adaptability (Duarte and Vencovsky, 1999). In contrast, the genotypes Abalone, BRS 296, BRS 328, BRS 331, BRS Guabiju, CD 114, CD 117, CD 119, CD 120, CD 122, CD 123, Fundacep 52, Fundacep Bravo, Fundacep Campo Real, Fundacep Cristalino, Fundacep Nova Era, Fundacep Raízes, JF 90, Onix, Safira, and Supera showed grain yield lower than the average of the experiment, being unstable. Adaptability was observed (Figure 1) for the genotypes G9 (BRS Guamirim) and G39 (TBIO Seleto), being specific to the environment A10 (São Luiz Gonzaga - RS, agricultural crop 2013), and genotypes G4 (BRS 327) and G32 (Quartzo) that were specific to the environment A7 (Santo Augusto - RS, agricultural crop 2013).

The environments evaluated individually contributed more to the $\mathrm{G} \times \mathrm{E}$ interaction than the effects of genotypes; this was evidenced by the greater dispersion of the vectors associated with the environments, concerning those associated with the genotypes (Figure 1). This trend has been observed in research that identified specific environmental factors involved in the manifestation of this type of interaction. The use of this technique allows to smooth the undesirable effects of the environments and to explore the positive attributes in an efficient way (Yokomizo et al., 2013).

The methods of Annicchiarico (1992) and AMMI infer that for the effects of environment there was no agreement between the methods for the grain yield character; this is due to the way in which the model obtains the estimates. However, for genotype effects, there was an agreement between the methods where CD 121 (G17) and TBIO Tibagi (G41) were stable and can be recommended to farmers for providing stability and high grain yield. Genotypes that present contradictory responses (Table 2), among the methods, were BRS Guamirim, TBIO Itaipu, TBIO Mestre, Seleto, TBIO Sinuelo, BRS 296, CD 117, CD 122, Fundacep Cristalino, JF 90, and Onix, all of which were stable for the method of Annicchiarico (1992).

By reconciling the Annicchiarico and AMMI methods, it is possible to infer important information for the seed production and breeding sectors, since it assists in efficient and reliable decision-making, which defines the best growing environments for the production of grains or seeds (Pereira et al., 2009).

Genetics and Molecular Research 16 (3): gmr16039735 


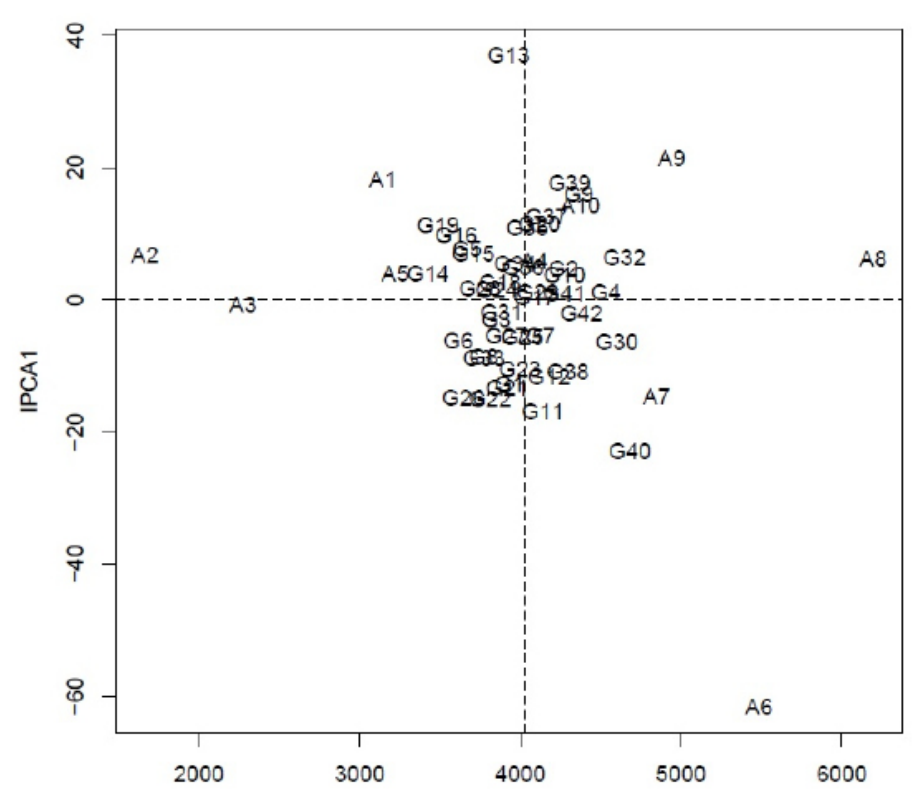

Figure 1. Plot of the main component scores for genotype $\mathrm{x}$ environment interaction ( $\mathrm{G} \times \mathrm{E})$, according to the AMMI model, for grain yield ( $\mathrm{kg} / \mathrm{ha}$ ) in two agricultural crops (2012 and 2013) for the 42 wheat genotypes (G1) Abalone, (G2) Ametista, (G3) BRS 296, (G4) BRS 327, (G5) BRS 328, (G6) BRS 331, (G7) BRS 374, (G8) BRS Guabiju, (G9) BRS Guamirim, (G10) BRS Louro, (G11) BRS Umbu, (G12) Campeiro, (G13) CD 114, (G14) CD 117, (G15) CD 119, (G16) CD 120, (G17) CD 121, (G18) CD 122, (G19) CD 123, (G20) FPS Nitron, (G21) Fundacep 52, (G22) Fundacep Bravo, (G23) Fundacep Campo Real, (G24) Fundacep Cristalino, (G25) Fundacep Horizonte, (G26) Fundacep Nova Era, (G27) Fundacep Raízes, (G28) JF 90, (G29) Marfim, (G30) Mirante, (G31) Onix, (G32) Quartzo, (G33) Safira, (G34) Supera, (G35) TBIO Alvorada, (G36) TBIO Iguaçu, (G37) TBIO Itaipu, (G38) TBIO Mestre, (G39) TBIO Seleto, (G40) TBIO Sinuelo, (G41) TBIO Tibagi, and (G42) Topázio, evaluated in ten growing environments, being Cachoeira do Sul - RS (A1:2012 and A6:2013), Passo Fundo - RS (A2:2012 and A7:2013), Santo Augusto - RS (A3:2012 and A8:2013), São Gabriel - RS (A4:2012 and A9:2013), and São Luiz Gonzaga - RS (A5:2012 and A10:2013).

Estimates of variance components and genetic parameters through the REML showed that genotypic variance $(\mathrm{Vg})$ was responsible for $12.2 \%$ of the phenotypic manifestation (Vf) of grain yield (Table 4). The presence of high genotypic variance may represent a greater contribution of this fraction to the G x E interaction (Silva et al., 2011). The grain yield (Vf) was influenced by $25.8 \%$ due to the interaction effects (Vint). The interaction (Vint) was determined by $48.6 \%$ due to the genetic effects, in this way, the results were concordant to those obtained by Pereira et al. (2015) in beans, where $59 \%$ of the phenotype was due to the G $\mathrm{x} E$ interaction. The influence of the environment on the interaction is due to the nature of the grain yield character, being controlled by many genes and its phenotypic expression is highly dependent on the characteristics of the growing environment (Piepho et al., 2012).

It was obtained high accuracy (Acgen) in the conduction of the experiment, which reveals good experimental quality and safety in the observation of the best genotypes for grain yield. The genotype correlation of the performance of genotypes in the growing environments (rgloc) makes it possible to classify the interaction in simple or complex, where the rgloc with high magnitude indicates simple interaction, with smaller distortions in the classification of the genotypes in the environments (Pupin et al., 2015). The low rgloc indicates the complex

Genetics and Molecular Research 16 (3): gmr16039735 
Table 3. Estimates of the adaptability and stability parameters by the AMMI method (additive main effects and multiplicative interaction analysis) for grain yield ( $\mathrm{kg} / \mathrm{ha}$ ) measured in 42 wheat genotypes (Triticum aestivum), evaluated in the growing environments: Cachoeira do Sul - RS, Passo Fundo - RS, Santo Augusto - RS, São Gabriel - RS, and São Luiz Gonzaga - RS in the crops 2012 and 2013.

\begin{tabular}{|c|c|c|c|c|c|}
\hline Genotypes & Average (kg/ha) & IPCA 1 & Genotypes & Average (kg/ha) & IPCA1 \\
\hline Abalone & 3931.1 & -12.666 & Fundacep Bravo & 3809.9 & -14.948 \\
\hline Ametista & 4265.6 & 4.751 & Fundacep Campo Real & 3996.3 & -10.435 \\
\hline BRS 296 & 3847.9 & -2.948 & Fundacep Cristalino & 3852.6 & 1.621 \\
\hline BRS 327 & 4530.9 & 1.124 & Fundacep Horizonte & 4012.7 & -5.634 \\
\hline BRS 328 & 3667.6 & 7.750 & Fundacep Nova Era & 3644.2 & -14.731 \\
\hline BRS 331 & 3612.2 & -6.217 & Fundacep Raízes & 3911.0 & -5.315 \\
\hline BRS 374 & 4122.4 & -5.352 & JF 90 & 3749.5 & 1.811 \\
\hline BRS Guabiju & 3770.7 & -8.680 & Marfim & 4106.9 & 1.175 \\
\hline BRS Guamirim & 4362.8 & 16.067 & Mirante & 4600.4 & -6.422 \\
\hline BRS Louro & 4273.3 & 3.878 & Onix & 3882.0 & -1.810 \\
\hline BRS Umbu & 4141.0 & -16.801 & Quartzo & 4646.4 & 6.394 \\
\hline Campeiro & 4177.3 & -11.620 & Safira & 3772.0 & -8.753 \\
\hline CD 114 & 3927.1 & 37.046 & Supera & 3966.2 & 5.536 \\
\hline CD 117 & 3424.3 & 4.061 & TBIO Alvorada & 4041.5 & 10.883 \\
\hline CD 119 & 3706.0 & 7.038 & TBIO Iguaçu & 4016.0 & 4.888 \\
\hline CD 120 & 3599.5 & 9.858 & TBIO Itaipu & 4160.8 & 12.647 \\
\hline CD 121 & 4089.0 & 0.498 & TBIO Mestre & 4294.5 & -10.862 \\
\hline CD 122 & 3872.5 & 2.578 & TBIO Seleto & 4304.6 & 17.771 \\
\hline CD 123 & 3486.5 & 11.296 & TBIO Sinuelo & 4681.7 & -22.757 \\
\hline FPS Nitron & 4117.0 & 11.499 & TBIO Tibagi & 4272.4 & 0.963 \\
\hline Fundacep 52 & 3917.6 & -13.235 & Topázio & 4379.2 & -1.949 \\
\hline \multicolumn{4}{|c|}{ Growing environments } & Yield (kg/ha) & IPCA 1 \\
\hline A1 & \multicolumn{3}{|c|}{ Cachoeira do Sul - RS, agricultural crop 2012} & 3142.5 & 18.182 \\
\hline A2 & \multicolumn{3}{|c|}{ Passo Fundo - RS, agricultural crop 2012} & 1663.1 & 6.788 \\
\hline $\mathrm{A} 3$ & \multicolumn{3}{|c|}{ Santo Augusto - RS, agricultural crop 2012} & 2272.1 & $-0,759$ \\
\hline A4 & \multicolumn{3}{|c|}{ São Gabriel - RS, agricultural crop 2012} & 4085.5 & 5.922 \\
\hline A5 & \multicolumn{3}{|c|}{ São Luiz Gonzaga - RS, agricultural crop 2012} & 3220.2 & 4.008 \\
\hline A6 & \multicolumn{3}{|c|}{ Cachoeira do Sul - RS, agricultural crop 2013} & 5485.1 & -61.571 \\
\hline A7 & \multicolumn{3}{|c|}{ Passo Fundo - RS, agricultural crop 2013} & 4847.0 & -14.507 \\
\hline A8 & \multicolumn{3}{|c|}{ Santo Augusto - RS, agricultural crop 2013} & 6195.9 & 6.248 \\
\hline A9 & \multicolumn{3}{|c|}{ São Gabriel - RS, agricultural crop 2013} & 4940.3 & 21.461 \\
\hline A10 & \multicolumn{3}{|c|}{ São Luiz Gonzaga - RS, agricultural crop 2013} & 4372.5 & 14.226 \\
\hline
\end{tabular}

interaction, which may hinder the selection and positioning of the genotypes towards the environments (Rosado et al., 2012). In this way, it was obtained rgloc of 0.32 , which indicated interaction of complex nature, favoring the selection of genotypes with specific adaptability (Table 4). Silva et al. (2011), in studies with sowing times, determined the adaptability and stability of the wheat, verifying genetic correlation of the genotypes among the environments, varying from 0.005 to 0.86 where the changes in the sowing period culminate in distortions in the origin of the interaction.

The genotypic coefficient of variation (CVgi) quantifies the percentage of the total variation due to the genetic effects; it was obtained $6.1 \%$ in the magnitude of this parameter, which indicates a high variability of the wheat genotypes studied for the grain yield character. This can be associated with the high number of genotypes tested in the experiment (Table 4). Research by Silva et al. (2011), when disintegrating the effects of crops and growing environments, obtained a coefficient of genotype variation of up to $15 \%$ for grain yield. High genotypic coefficients indicate greater accuracy in the selection practices of the superior genotypes (Resende and Duarte, 2007). The residual coefficient of variation (CVr) was low (0.44), confirming the adequate conduction of the experiment.

The MHPRVG ranked the genotypes and estimated the phenotypic adaptability and stability. The selection of the ten best genotypes, corresponding to $23.8 \%$ of the genotypes 
studied, was used as the criterion. It was verified, through MHPRVG, superiority for the genotypes TBIO Sinuelo, Quartzo, BRS 327, Mirante, Topázio, Guamirim, TBIO Seleto, Ametista, TBIO Mestre, and BRS Louro, consecutively. The genotype TBIO Sinuelo revealed a $14 \%$ higher yield than the general average of the experiment. The other genotypes were $7.5 \%$ higher than the average (Table 4), these genotypes can be considered as promising for the next crops.

Table 4. Ranking results obtained by the weighted harmonic mean of the genotypic values (MHPRVG) obtained for the 42 wheat genotypes grown in ten environments in the State of Rio Grande do Sul.

\begin{tabular}{|c|c|c|c|c|c|}
\hline \multicolumn{6}{|c|}{ Variance components (individual REML) } \\
\hline $\mathrm{Vg}$ & \multicolumn{4}{|c|}{ Genotypic variance } & $62,414.049$ \\
\hline Vint & \multicolumn{4}{|c|}{ Genotype $\mathrm{x}$ environment interaction variance } & $128,366.558$ \\
\hline $\mathrm{Ve}$ & \multicolumn{4}{|c|}{ Residual variance } & $320,546.535$ \\
\hline $\mathrm{Vf}$ & \multicolumn{4}{|c|}{ Individual phenotypic variance } & $511,327.143$ \\
\hline $\mathrm{h} 2 \mathrm{~g}=\mathrm{h} 2$ & \multicolumn{4}{|c|}{ Heritability of individual parcels in the broad sense } & 0.122063 \\
\hline h2mg & \multicolumn{4}{|c|}{ Heritability of the genotype average, assuming complete survival } & 0.726 \\
\hline Acgen & \multicolumn{4}{|c|}{ Accuracy of genotype selection, assuming complete survival } & 0.852 \\
\hline c2int & \multicolumn{4}{|c|}{ Coefficient of determination of the genotype $\mathrm{x}$ environment interaction effects } & 0.251 \\
\hline rgloc & \multicolumn{4}{|c|}{ Genotype correlation of the performance of genotypes among the growing environment } & 0.327 \\
\hline CVgi \% & \multicolumn{4}{|c|}{ Genotypic coefficient of variation } & 6.162 \\
\hline $\mathrm{CVr} \%$ & \multicolumn{4}{|c|}{ Residual coefficient of variation } & 13.965 \\
\hline General average & \multicolumn{4}{|c|}{ General average of the experiment } & $4,054.128$ \\
\hline Genotypes & Order & Yield (kg/ha) & Genotypes & Order & Yield (kg/ha) \\
\hline Abalone & 25 & $3,937.6$ & Fundacep Bravo & 34 & $3,823.2$ \\
\hline Ametista & 8 & $4,274.2$ & Fundacep Campo Real & 17 & $4,112.7$ \\
\hline BRS 296 & 35 & $3,778.0$ & Fundacep Cristalino & 29 & $3,901.5$ \\
\hline BRS 327 & 3 & $4,513.2$ & Fundacep Horizonte & 23 & $4,016.2$ \\
\hline BRS 328 & 37 & $3,687.7$ & Fundacep Nova Era & 32 & $3,846.4$ \\
\hline BRS 331 & 41 & $3,547.9$ & Fundacep Raízes & 27 & $3,907.1$ \\
\hline BRS 374 & 22 & $4,062.6$ & JF 90 & 33 & $3,836.2$ \\
\hline BRS Guabiju & 31 & $3,866.7$ & Marfim & 21 & $4,070.6$ \\
\hline BRS Guamirim & 6 & $4,346.2$ & Mirante & 4 & $4,508.4$ \\
\hline BRS Louro & 10 & $4,242.2$ & Onix & 30 & $3,896.8$ \\
\hline BRS Umbu & 18 & $4,098.4$ & Quartzo & 2 & $4,596.6$ \\
\hline Campeiro & 14 & $4,137.9$ & Safira & 36 & $3,772.3$ \\
\hline CD 114 & 15 & $4,125.7$ & Supera & 26 & $3,907.9$ \\
\hline CD 117 & 40 & $3,584.7$ & TBIO Alvorada & 20 & $4,076.6$ \\
\hline CD 119 & 38 & $3,687.2$ & TBIO Iguaçu & 24 & $4,012.5$ \\
\hline CD 120 & 39 & $3,590.5$ & TBIO Itaipu & 13 & $4,163.3$ \\
\hline CD 121 & 12 & $4,174.6$ & TBIO Mestre & 9 & $4,257.8$ \\
\hline CD 122 & 28 & $3,901.5$ & TBIO Seleto & 7 & $4,333.4$ \\
\hline CD 123 & 42 & $3,540.2$ & TBIO Sinuelo & 1 & $4,622.8$ \\
\hline FPS Nitron & 19 & $4,088.1$ & TBIO Tibagi & 11 & $4,237.1$ \\
\hline Fundacep 52 & 16 & $4,120.7$ & Topázio & 5 & $4,361.4$ \\
\hline
\end{tabular}

By using the univariate, multivariate, and mixed models, it can be inferred that the genotypes TBIO Sinuelo, Quartzo, BRS 327, Mirante, TBIO Seleto, BRS Guamirin, Topázio, Ametista, and BRS Louro showed higher stability in the Annicchiarico (1992) method. For the AMMI method, the genotypes CD 121 and TBIO Tibagi were stable and highly productive. The weighted harmonic mean of the MHPRVG genotypic values showed superiority for the genotypes TBIO Sinuelo, Quartzo, BRS 327, Mirante, Topázio, Guamirim, TBIO Seleto, Ametista, TBIO Mestre, and BRS Louro. The concomitant use of these methods provides advantages to breeding and seed production practices since it assists in the selection and positioning of wheat genotypes in the conditions of the State of Rio Grande do Sul.

The favorable environments expressed by the univariate method refer to São GabrielRS, Cachoeira do Sul-RS, Passo Fundo-RS, Santo Augusto-RS, and São Luiz Gonzaga-RS, for the multivariate method only Santo Augusto-RS is favorable to grain yield of wheat. 
The genotypes CD 121 and TBIO Tibagi are adapted and stable for the univariate and multivariate method. The genotypes TBIO Sinuelo, Quartzo, BRS 327, Mirante, Topázio, Guamirim, TBIO Seleto, Ametista, TBIO Mestre, and BRS Louro are superior through the mixed model approach.

The different strategies to estimate the adaptability and phenotypic stability allow indicating and recommending the best environments and genotypes efficiently to obtain increases in wheat grain yield.

\section{Conflicts of interest}

The authors declare no conflict of interest.

\section{ACKNOWLEDGMENTS}

The authors thank Coordenação de Aperfeiçoamento de Pessoal de Nível Superior (CAPES) for project financing and the granting of the first author's doctoral fellowship. V.Q de Souza and T.Z. Aumonde received a 2A productivity scholarship from CNPq.

\section{REFERENCES}

Ahmadi J, Mohammadi A and Mirak N (2012). Targeting promising bread wheat (Triticum aestivum L.) lines for cold climate growing environments using AMMI and SREG GGE Biplot analyses. J. Agric. Sci. Technol. 14: 645-657.

Allard RW (1971). Princípios do Melhoramento Genético das Plantas. USAID/Edgard Blucher, Rio de Janeiro.

Alvarez MP and Eyhérabide GH (1996). Estabilidad del rendimento de cultivares de híbidoscomerciales de maíz em la área de la EEA Pergamino. Rev. Tecnol. Agropec 5: 17-21.

Amorim EP, Camargo CEO, Filho AWPF, Junior AP, et al. (2006). Adaptabilidade e estabilidade de linhagens de trigo no Estado de São Paulo. Bragantia 65: 575-582 https://doi.org/10.1590/S0006-87052006000400007.

Annicchiarico P (1992). Cultivar adaptation and recommendation from alfafa trials in Northern Italy. J. Gen. Plant Breed 46: $269-278$

Benin G, Pinnow C, Silva CL, Pagliosa ES, et al. (2012). Análises biplot na avaliação de cultivares de trigo em diferentes níveis de manejo. Bragantia 71: 28-36 https://doi.org/10.1590/S0006-87052012000100005.

Campbell BT and Jones MA (2005). Assesment of genotype $\mathrm{x}$ environment interactions for yield and fiber quality in cotton performance trials. Euphytica 144: 69-78. https://doi.org/10.1007/s10681-005-4336-7

Castillo D, Matus I, Pozzo A, Madariaga R, et al. (2012). Adaptability and genotype times environment interaction of spring wheat cultivars in Chile using regression analysis, AMMI, and SREG. Chil. J. Agric. Res. 72: 167. https://doi. org/10.4067/S0718-58392012000200001

CONAB - Companhia Nacional de Abastecimento (2012). Acompanhamento da safra brasileira de grãos. $3^{\circ}$ Levantamento Grãos Safra 2012/13 - Setembro 2012. Available at [http://www.conab.gov.br/OlalaCMS/uploads/ arquivos/14 $01 \quad 10 \quad 10 \quad 1236$ boletim portugues dezembro 2012.pdf]. Accessed October 7, 2016.

Condé ABT, Coelho MAO, Yamanaka CH and Corte HR (2010). Adaptabilidade e estabilidade de genótipos de trigo sob cultivo de sequeiro em Minas Gerais. Pesqui. Agropecu. Trop. 40: 45-52.

Cruz CD (2013). GENES - a software package for analysis in experimental statistics and quantitative genetics. Acta Scientiarum 35: 271-276.

Cruz CD, Carneiro PCS and Regazzi AJ (2014). Modelos biométricos aplicados ao melhoramento genético. 3 ed. Editora da UFV, Viçosa.

Da Silva GO, De Carvalho ADF, Souza ZS, Ponijaleki RS, et al. (2016). Desempenho genotípico de clones de batata via modelos mistos. Agraria 11: 259-266 https://doi.org/10.5039/agraria.v11i4a5390.

Duarte JB and Vencovsky R (1999). Interação genótipo x ambiente: uma introdução à análise "AMMI". Sociedade Brasileira de Genética, Ribeirão Preto.

Junior OP (2014). Aptidão, adaptabilidade e estabilidade fenotípica de genótipos de trigo. Dissertação (Mestrado em Agronomia) - Departamento de Produção Vegetal da Universidade Estadual do Centro-Oeste (UNICENTRO), Guarapuava.

Genetics and Molecular Research 16 (3): gmr16039735 
Ma BL, Yan W, Dwyer LM, Fregeau-Reid J, et al. (2004). Graphic analysis of genotype, environment, nitrogen fertilizer, and their interactions on spring wheat yield. Agron. J. 96: 169-180.

Oliveira AB, Duarte JB and Pinheiro JB (2003). Emprego da análise AMMI na avaliação da estabilidade produtiva em soja. Pesqui. Agropecu. Bras. 38: 357-364 https://doi.org/10.1590/S0100-204X2003000300004.

Oliveira DM, Souza MA, Rocha VS, Assis JC, et al. (2011). Desempenho de genitores e populações segregantes de trigo sob estresse de calor. Bragantia 70: 25-32 https://doi.org/10.1590/S0006-87052011000100005.

Pereira HS, Melo LC, Peloso MJD, Faria LC, et al. (2009). Comparação de métodos de análise de adaptabilidade e estabilidade fenotípica em feijoeiro-comum. Pesqui. Agropecu. Bras. 44: 374-383 https://doi.org/10.1590/S0100$204 X 2009000400007$.

Pereira TCV, Schmit R, Haveroth EJ, Melo RC, et al. (2015). Reflexo da interação genótipo x ambiente sobre o melhoramento genético de feijão. Cienc. Rural 46: 411-417 https://doi.org/10.1590/0103-8478cr20130998.

Piepho HP, Williams ER and Maddlen LV (2012). The use of two-way linear mixed models in multitreatment metaanalysis. Biometrics 68: 1269-1277.

Pimentel Gomes F (2009). Curso de estatística experimental. 15 ed. FEALQ, Piracicaba.

Pupin S, Dos Santos AVDA, Zaruma DUG, Miranda AC, et al. (2015). Produtividade, estabilidade e adaptabilidade em progênies de polinização aberta de Eucalyptus urophylla ST Blake. Sci. For. 43: 127-134.

R Core Team (2015). R: A language and environment for statistical computing. R Foundation for Statistical Computing, Vienna, Austria.

Ramalho MAP and Araújo LCA (2011). Breeding self-pollinated plants. Crop Breed. Appl. Biotechnol. 11: 1-7 https://doi. org/10.1590/S1984-70332011000500002.

Ramalho MAP, Ferreira DF and Oliveira AC (2000). Experimentação em genética e melhoramento de plantas. UFLA, Lavras.

Resende MDV (2002). Genética biométrica e estatística no melhoramento de plantas perenes. Embrapa Informação Tecnológica, Brasília. Embrapa Florestas, Colombo.

Resende MDV (2007). Software SELEGEN-REML/BLUP: sistema estatístico e seleção genética computadorizada via modelos lineares mistos. Embrapa Florestas, Colombo.

Resende MDV (2016). Software Selegen-REML/BLUP: a useful tool for plant breeding. Crop Breed. Appl. Biotechnol. 16: 330-339 https://doi.org/10.1590/1984-70332016v16n4a49.

Resende MDV and Duarte JB (2007). Precisão e controle de qualidade em experimentos de avaliação de cultivares. Pesqui. Agropecu. Trop. 37: 182-194.

Rodríguez GRE, Medina PJ, Puente EO, Reyes LA, et al. (2011). Interacción genotipo-ambiente para la estabilidad de rendimiento en trigo en la región de Mexicali, BC. México. Trop. Subtrop. Agroecosyt 14: 543-558.

Rosado AM, Rosado TB, Alves AA, Laviola BG, et al. (2012). Seleção simultânea de clones de eucalipto de acordo com produtividade, estabilidade e adaptabilidade. Pesqui. Agropecu. Bras. 47: 964-971 https://doi.org/10.1590/S0100204X2012000700013.

Silva RR and Benin G (2012). Análises Biplot: conceitos, interpretações e aplicações. Cienc. Rural 42: 1404-1412 https:// doi.org/10.1590/S0103-84782012000800012.

Silva RR, Benin G, Silva GO, Marchioro VS, et al. (2011). Adaptabilidade e estabilidade de cultivares de trigo em diferentes épocas de semeadura, no Paraná. Pesqui. Agropecu. Bras. 46: 1439-1447 https://doi.org/10.1590/S0100204X2011001100004.

Silveira DA, Princinotto LF, Nardino M, Bahry CA, et al. (2016). Determination of the adaptability and stability of soybean cultivars in different locations and at different sowing times in Paraná state using the AMMI and Eberhart and Russel methods. Semin. Cienc. Agrar. 37: 3973-3982 https://doi.org/10.5433/1679-0359.2016v37n6p3973.

Spilke J, Phiepho HP and Hu X (2005). Analysis of unbalanced data by mixed linear models using the Mixed Procedure of the SAS System. J. Agron. Crop Sci. 191: 47-54.

Streck EV, Kämpf N, Dalmolin RSD, Klamt E, et al. (2008). Solos do Rio Grande do Sul. 2 ed. Emater, Porto Alegre.

Yan W and Kang MS (2003). GGE biplot analysis: A graphical tool for breeders, geneticists, and agronomists. CRC Press, Boca Raton.

Yokomizo GKI, Duarte JB, Vello NA and Unfried JR (2013). Análise AMMI da produtividade de grãos em linhagens de soja selecionadas para resistência à ferrugem asiática. Pesqui. Agropecu. Bras. 48: 1372-1380 https://doi.org/10.1590/ S0100-204X2013001000009.

Zobel RW, Wright MJ and Gauch HG (1988). Statistical analysis of a yield trial. Agron. J. 80: 388-393.

Genetics and Molecular Research 16 (3): gmr16039735 